\title{
J. Górniewicz, Teoria wychowania (wybrane problemy) Olsztyńska Szkoła im. Józefa Rusieckiego, Olsztyn 2007, s. 187
}

Zagadnienie wychowania jest tak stare, jak refleksja nad człowiekiem. I jak długo filozofowie, antropolodzy, pedagodzy będą snuć tę refleksję, tak długo w kontekście ich rozważań, pojawiać się będzie kwestia wychowania i jego roli w życiu człowieka. Jednakże trzeba stwierdzić, iż mimo systematycznie prowadzonych rozważań teoretycznych, czasy współczesne charakteryzuje jednak niepokojąca utrata świadomości tej roli, która często rozumiana jest raczej jako towarzyszenie, dawanie wykształcenia niż wychowanie sensu stricto. Tymczasem konieczność wychowania jest niezbędna i niepodważalna (mimo iż niektórzy wbrew temu, co podpowiada sensus communis kwestionują je), gdyż człowiek jest bytem niedoskonałym, a niedoskonałość ta dotyka wielu obszarów jego egzystencji. Człowiek jako byt „niedokończony” potrzebuje bycia wychowywanym już od najwcześniejszych miesięcy życia, a proces ten nie kończy się bynajmniej wraz z osiągnięciem osiemnastu lat czy otrzymaniem świadectwa dojrzałości, ale trwa właściwie przez całe życie człowieka. Analizując problematykę wychowania, dotyka się zagadnienia, które stanowi relewantny i delikatny teren poszukiwań, a zarazem życiowo niezwykle doniosły. Wychowanie przecież należy do najtrudniejszych i największych zadań ludzkiej egzystencji. Dlatego niedociągnięcia lub pomyłki różnych teorii wychowawczych, często niekomplementarnych lub jednoaspektowo wybiórczych, nie pozostają tylko błędnie wypracowanymi koncepcjami, ale mają także kolosalne znaczenie praktyczne. Wychowanie, jak pokazują to dzieje myśli ludzkiej, nie jest ani proste ani łatwe do ostatecznego zdefiniowania. Wydaje się, że nie można nawet mówić o jakiejś całościowej czy uniwersalnej definicji wychowania, którą można byłoby zaaplikować do wszystkich epok i społeczeństw, ponieważ każde społeczeństwo, w każdym okresie kulturowym i historycznym, posiada własny ideał wychowania, i stosownie do swych potrzeb i warunków życia wypracowuje specyficzne działania wychowawczo-pedagogiczne. Sama historia wychowania potwierdza jednoznacznie, iż cały system wychowawczy jako zbiór sposobów, metod i doświadczeń zdobytych na bazie struktury społecznej i stanu umysłowego społeczeństwa jest dostosowany do danego kontekstu geograficzno-historyczno-społecznego. W wychowaniu zawsze występują także zadania zmienne podyktowane przez potrzeby ludzi współczesnych danej epoki, ich ciągłe przeobrażające się okoliczności życia, ich coraz to inne sposoby przeżywania rzeczywistości. W człowieku, zwłaszcza młodym, dostrzega się reperkusje zdarzeń i przemian życia bieżącego, w którym dokonuje się wieloaspektowy rozwój. 
Epoka, w której żyjemy, zwana epoką postmodernistyczną, często skrajnie interpretująca fakt wychowania, szybki rozwój cywilizacji naukowo-technicznej i silne zakotwiczenie w niej, wzrost rozmaitych przemian, i w kolosalnym tempie rozwijająca się działalność środków porozumienia interpersonalnego i komunikacji społecznej, czyni zasadnym kolejne próby zdefiniowania problematyki wychowania, dostosowanej do nowych wyzwań współczesności. Wychowaniem zatem zajmują się przedstawiciele różnych dyscyplin, gdyż proces wychowania jest zjawiskiem tak skomplikowanym, iż należy nań spojrzeć z punktu widzenia jak najszerszego spektrum różnorakich nauk. Jednak najbardziej wyczerpującej odpowiedzi na pytanie: czym jest wychowanie w całej swej złożoności, udzielają ci autorzy, którzy jako pedagodzy stricte badają zjawisko wychowania na gruncie teorii wychowania, będącej autonomiczną nauką, mającą już swoje tradycje i metodę. Jednym $\mathrm{z}$ tych autorów jest prof. Józef Górniewicz, prorektor Uniwersytetu Warmińsko-Mazurskiego, autorytet we współczesnej pedagogice, który w swej książce Teoria wychowania, precyzyjnie i wielowymiarowo wyjaśnia, czym jest wychowanie i jaki jest aktualny stan wiedzy w dziedzinie dyscypliny akademickiej, którą zwie się teorią wychowania, a która wykładana jest na wszystkich uczelniach wyższych kształcących pedagogów. Książka J. Górniewicza jest więc niezwykle przydatnym podręcznikiem nie tylko dla studentów pedagogiki, ale dla tych wszystkich, którym ta problematyka jest bliska $\mathrm{z}$ racji podejmowanych działań wychowawczych zarówno na płaszczyźnie spekulacji teoretycznych, jak i na płaszczyźnie edukacyjnej praxis.

Recenzowana praca została podzielona na cztery komplementarne rozdziały. Pierwszy z nich poświęcony został podstawowym pojęciom teorii wychowania, jak: wychowanie, socjalizacja, podmiotowość, partnerstwo, samorealizacja czy też samowychowanie. Te doprecyzowania terminologiczne są potrzebne, aby uświadomić czytelnikowi, że wychowanie to w istocie niezwykła ars artium et scientia scientiarum, jak wychowanie określił św. Grzegorz z Nazjanzu. I w istocie, wychowanie to $\mathrm{w}$ rezultacie wiedza i sztuka doprowadzania człowieka do jego pełni, czynienia go, jak mawiali starożytni Grecy kallos kai agatos - pięknym i dobrym. W rozdziale drugim autor skupia się na ustaleniach metodologicznych charakterystyki teorii wychowania, analizując miejsce teorii wychowania w naukach pedagogicznych, ustalając przedmiot teorii wychowania, jej status naukowy, opisując orientacje badawcze w teorii wychowania i funkcje teorii wychowania. W świetle ustaleń autora teoria wychowania jawi się jako jedna z podstawowych dziedzin myśli pedagogicznej i centrum refleksji nad różnymi kontekstami wychowania, i jako taka powiązana jest ona $\mathrm{z}$ wieloma subdyscyplinami, które pogłębiają refleksję nad wychowaniem, np. teleologia wychowania, aksjologia wychowania, czy choćby antropologia filozoficzna, bez której trudno nawet wyobrazić sobie rozsądną, konstruktywną i uprawnioną metodologicznie teorię wychowania. Trzeci rozdział autor dedykuje strukturze 
procesu wychowania, omawiając ów proces w aspekcie ideału wychowania, celu i formy wychowania, a także metod i środków wychowania. Józef Górniewicz w kontekście tym podkreśla więc, że na strukturę wychowania składa się zarówno warstwa aksjologiczna, którą można by też nazwać aksjonormatywną, jak i warstwa operacyjna, którą określiłabym aretologiczno-eudajmonologiczną. Autor omawia obie te warstwy także w kontekście różnorakich stanowisk, które pojawiają się na gruncie literatury pedagogicznej. W ostatnim rozdziale zatytułowanym „Dziedziny wychowania” prof. Górniewicz koncentruje się na omówieniu poszczególnych obszarów wychowania, rozpoczynając swą refleksję od niewątpliwie jednego z ważniejszych aspektów wychowania, mianowicie wychowania moralnego. Ta dziedzina wychowania jest w istocie najważniejszym elementem całości formacji człowieka, który, będąc in statu viae, wciąż dąży do osiągnięcia maksimum bytu, do jakiegoś dojścia do „kresu” samego siebie, ponieważ człowiek nie jest nigdy "gotowy”, a jedynie przeznaczony do rozwinięcia posiadanych zadatków i aktualizacji posiadanych potencjalności. Autor w tymże kontekście ukazuje rozmaite współczesne problemy wychowania moralnego, na które mogą natknąć się wychowawcy, rodzice i nauczyciele. Rozdział ten omawia również zagadnienia wychowania estetycznego, wychowania umysłowego, a także zdrowotnego i fizycznego, które są integralnymi elementami całego procesu wychowawczego i bez których proces ten byłby niepełny i jednostronny. Praca uzupełniona jest bogatą bibliografią omawianej problematyki, która przywoływana była w tekście książki.

Teoria wychowania J. Górniewicza jest pozycją, która rzeczowo analizuje problematykę wychowania, wprowadzając $\mathrm{w}$ zakres zasadniczych zagadnień, z którymi wychowawcy i pedagodzy stykają się na co dzień w praktyce edukacyjnej. Dodatkowo walorem tej książki jest nakreślenie intelektualnego dorobku, jaki w tej materii istnieje, a który może stać się punktem wyjścia do osobistych poszukiwań i konstatacji. Wszyscy zatem zainteresowani problematyką wychowania, a także chcący skonfrontować swe pojęcia o wychowaniu z refleksjami autorytetu w tej dziedzinie (a zainteresowanych jest niemało, na co wskazuje już szóste wydanie tego podręcznika), znajdą w książce J. Górniewicza znakomitą pozycję do studiów, zbliżających ich do pełniejszego i całościowego ujęcia tej niezwykłej rzeczywistości, jaką jest wychowanie człowieka.

Zdzisława Kobylińska

Olsztyn 